\title{
Crustal structure of the southwestern margin of the Kuril arc sited in the eastern part of Hokkaido, Japan, inferred from seismic refraction/reflection experiments
}

\author{
Eiji Kurashimo ${ }^{1}$, Takaya Iwasaki ${ }^{1}$, Naoshi Hirata ${ }^{1}$, Tanio Ito $^{2}$, and Yoshiyuki Kaneda ${ }^{3}$ \\ ${ }^{1}$ Earthquake Research Institute, the University of Tokyo, 1-1-1 Yayoi, Bunkyo-ku, Tokyo 113-0032, Japan \\ ${ }^{2}$ Department of Earth Sciences, Faculty of Science, Chiba University, 1-33 Yayoi-cho, Inage-ku, Chiba 263-8522, Japan \\ ${ }^{3}$ Japan Agency for Marine-Earth Science and Technology, 2-15 Natsuhima-cho, Yokosuka 237-0061, Japan \\ (Received April 12, 2006; Revised December 28, 2006; Accepted February 13, 2007; Online published June 8, 2007)
}

\begin{abstract}
Hokkaido Island in northern Japan is located at the intersection of the Kuril and Northeast Japan arcs. Eastern Hokkaido represents the southwestern margin of the Kuril arc that evolved as an oceanic island arc, but its crustal structure has remained unclarified. In the summer of 2000, a highly dense onshore-offshore integrated seismic experiment was conducted in order to reveal the entire crustal section covering from the Kuril Trench to the back-arc basin of the Okhotsk Sea crossing eastern Hokkaido. High-quality refraction/wide-angle reflection data collected for the onshore survey line delineated a detailed crustal structure of easternmost part of Hokkaido Island. Our seismic velocity model shows a good correlation with the surface geology along the profile. The notable feature of the velocity model is the existence of a $6.0-\mathrm{km} / \mathrm{s}$ layer beneath the onshore survey line. A reflective middle to lower crust is also found beneath eastern Hokkaido. These results indicate that the southwestern margin of the Kuril arc is in a matured state of oceanic island-arc crust.
\end{abstract}

Key words: Crustal structure, southwestern margin of the Kuril arc, seismic refraction and reflection experiments, mature oceanic island-arc crust.

\section{Introduction}

Hokkaido Island in northern Japan is located at the intersection of two active island arc-trench systems: the Northeast Japan arc-Japan Trench and the Kuril arc-Kuril Trench systems (Fig. 1). Hokkaido is divided into three major provinces with regard to its pre-Neogene geology whose general trend is oblique to these arc-trench systems: Western, Central, and Eastern Hokkaido (e.g. Arita et al., 1998). Western Hokkaido is the northern extension of the Northeast Japan arc, which consists of a late Jurassic accretionary complex with Cretaceous granitic intrusion (e.g. Kawamura et al., 1986; Kimura, 1994). Central Hokkaido is composed of Cretaceous to early Paleogene accretionary complexes often covered by forearc basin sediments (e.g. Kimura, 1994). Eastern Hokkaido represents the southwestern margin of the Kuril arc, whose oldest rocks are the latest Cretaceous andesitic volcanic and sedimentary rocks, which probably form the ancient Kuril arc (Kimura and Tamaki, 1985; Kimura, 1994). The crustal evolution of Hokkaido Island has been dominated by a series of accretion and collision processes occurring from the late Jurassic to the present. Several tectonic models for Hokkaido have been proposed. Kimura $(1994,1996)$ suggested that the ancient Kuril arc situated along the southern margin of the Okhotsk Plate collided with the Asian continental margin in the late Eocene. After this collision, the northern part

Copyright (c) The Society of Geomagnetism and Earth, Planetary and Space Sciences (SGEPSS); The Seismological Society of Japan; The Volcanological Society of Japan; The Geodetic Society of Japan; The Japanese Society for Planetary Sciences; TERRAPUB of the Okhotsk Sea was trapped, which caused the cessation of subduction along Hokkaido, Sakhalin, and the southern margin of Siberia, with only the Kuril trench surviving. Since the late Miocene, the Kuril forearc sliver has been migrating southwestward and colliding with the Northeast Japan arc (e.g. Kimura, 1986) due to the oblique subduction of the Pacific Plate along the Kuril trench. In order to investigate the structural variations and deformations associated with the accretion and collision tectonics in Hokkaido, several controlled-source seismic experiments including refraction and reflection profiling were conducted (e.g. Arita et al., 1998; Iwasaki et al., 1998; Tsumura et al., 1999; Iwasaki et al., 2004).

The easternmost part of Hokkaido is geologically considered to be the southern margin of the Kuril arc. Although the Japan National Oil Corporation (JNOC) conducted several seismic reflection experiments (JNOC, 1984, $1985,1990,2002)$ in this region, these studies shed light only upon a shallow crustal structure, and little is known about the entire crustal structure. In the summer of 2000 , a highly dense onshore-offshore integrated seismic experiment was conducted in order to reveal the crustal section from the Kuril Trench to the back-arc basin of the Okhotsk Sea crossing eastern Hokkaido, which corresponds to the southwestern margin of the Kuril arc. Nakanishi et al. (2004) showed the detailed crustal and uppermost mantle structural model across the seismogenic zone of the southern Kuril Trench from off-shore data. In this paper we present the crustal structure beneath eastern Hokkaido obtained from on-shore data and discuss the maturity level of 


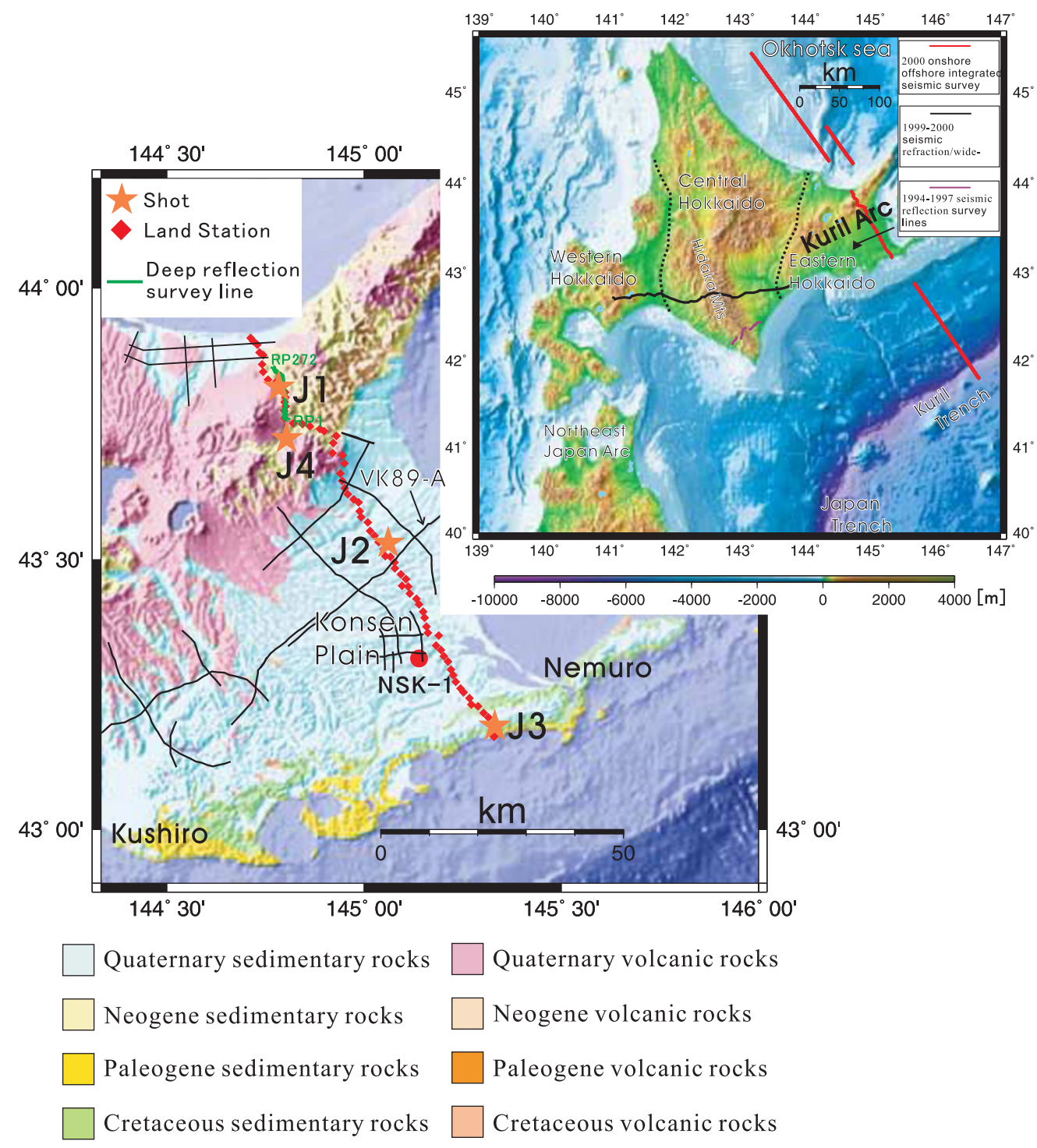

Fig. 1. Location map of the 2000 onshore-offshore integrated seismic experiment across eastern Hokkaido, Japan. The survey lines are shown in red. The renection lines carried out from 1994 to 1997 (Tsumura et al., 1999) and refraction/wide-angle renection lines carried out in 1999-2000 (Iwasaki et al., 2004) are also shown. The explosive shots (star symbols) and the land seismic stations (diamond symbols) are shown with a simplined geological map (Geological Survey of Japan, 1992). The green line denotes the deep seismic redection survey line using a digital telemetry recording system. The red circle symbol labeled 'NSK-1' denotes the drilling site (JNOC, 2002). The black lines denote previous seismic reqection survey lines conducted by the Japan National Oil Corporation (JNOC, 1984, 1985, 1990, 2002). The seismic redection prodle along the VK89-A was reported by JNOC (1985).

the southwestern margin of the Kuril arc crust. According to Kimura (1996), the Kuril arc is an oceanic island arc. However, previous wide-angle seismic investigations in the eastern half of the Hokkaido Island provide no positive evidence of an oceanic island arc. The easternmost part of the Hokkaido has been less affected by the collision than previous survey areas, therefore, its crustal structure is expected to contain some information on the crustal evolution on the southwestern margin of the Kuril arc.

\section{Experiments and Data}

In the summer of 2000, a highly dense onshore-offshore integrated seismic experiment was conducted in order to reveal the crustal section from the Kuril Trench to the backarc basin of the Okhotsk Sea crossing eastern Hokkaido (Fig. 1). Seventy-four portable seismographs were de- ployed onshore along a 95-km-long line in the northnorthwest-south-southwest direction at intervals of 1-1.5 $\mathrm{km}$. Each seismograph consisted of a $4.5-\mathrm{Hz}$ threecomponent seismometer and a long-term low-power digital audio tape (DAT) recorder (Shinohara et al., 1997). Waveforms were recorded at a sampling rate of $100 \mathrm{~Hz}$. Each DAT recorder included a global positioning system (GPS) receiver to maintain the accuracy of its internal clock. Four explosives were ared as a controlled seismic source on the onshore survey line. The charge sizes were $300 \mathrm{~kg}$ at $\mathrm{J} 1$ and $\mathrm{J} 3$ and $100 \mathrm{~kg}$ at $\mathrm{J} 2$ and $\mathrm{J} 4$. Moreover, we conducted deep seismic renection pronling in order to reveal the distribution of the deep redections at the northern part of the onshore survey line (Fig. 1). The seismic signals from the explosive sources (J1-J4) were also recorded with a digital telemetry seismic recording system with 272 channels at a 

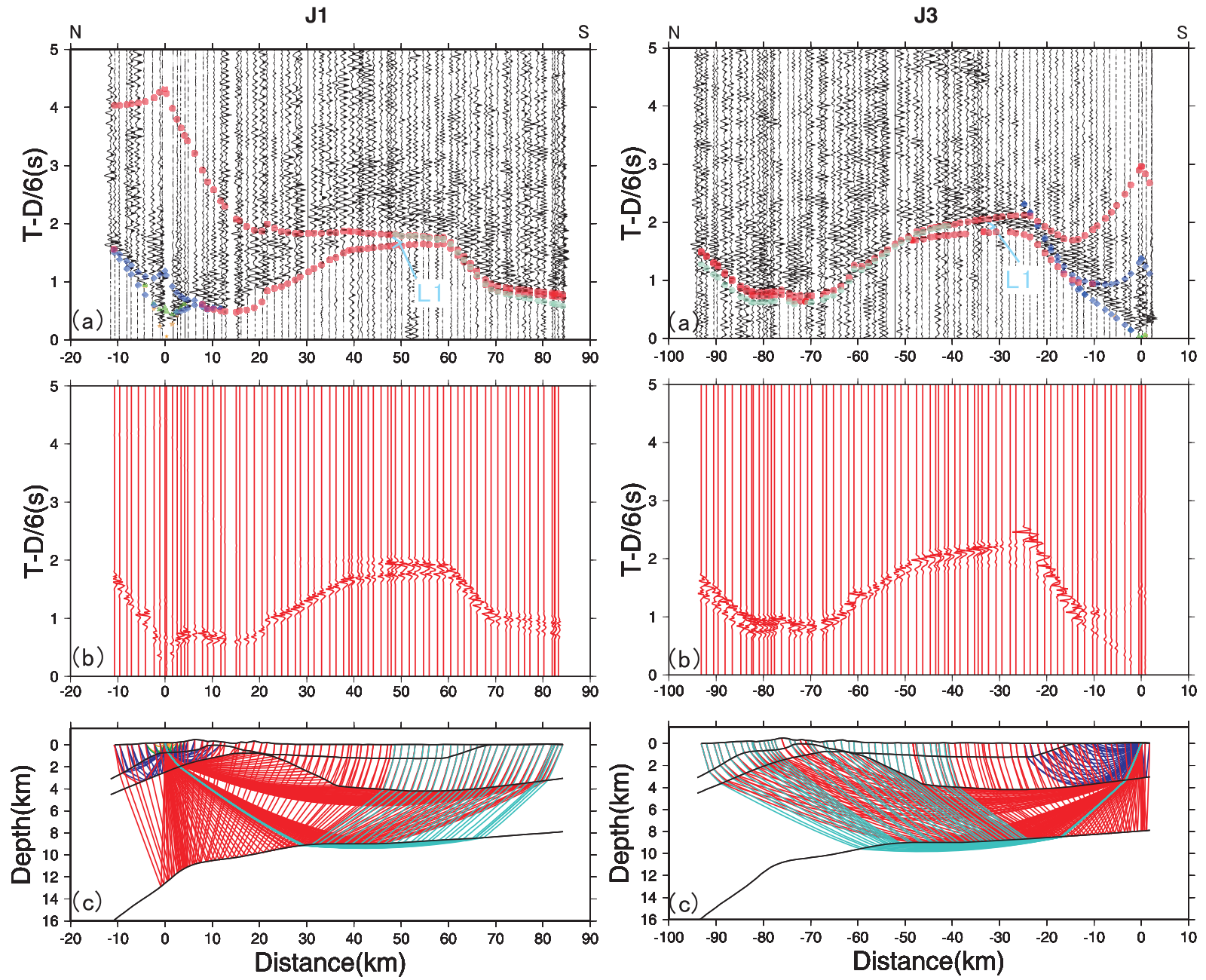

Fig. 2. Observed seismograms, calculated travel times, synthetic seismograms, and ray diagrams for shots J1 (left) and J3 (right). The horizontal axis represents the source-receiver offset. (a) Observed seismograms. Band-pass alter $(1-25 \mathrm{~Hz})$ is applied. Each trace is normalized by its maximum amplitude. The reduction velocity is $6 \mathrm{~km} / \mathrm{s}$. We obtained high signal-to-noise ratio data along the entire length of the onshore survey line. The calculated travel times for the nnal crustal model (Fig. 3) are superimposed on the observed seismograms. (b) Ray theoretical synthetic seismograms. (c) Ray diagram. The ray paths and calculated travel times correspond in color.

sampling rate of $250 \mathrm{~Hz}$. A 50-m group interval of $10-\mathrm{Hz}$ geophones was used. We obtained high signal-to-noise ratio data along the entire length of the onshore survey line (Fig. 2).

\section{Analysis and Results}

\subsection{Two-dimensional velocity structure}

The two-dimensional (2-D) velocity structure beneath eastern Hokkaido was derived by a 2-D ray-tracing method using the arst arrivals and later phases observed on the survey line so as to determine the velocities and the geometry of the velocity interface. In order to construct an initial model of the ray-tracing analysis, the arst arrivals from J1-J4 were inverted by using an extended time-term method (Iwasaki, 2002) so as to obtain the rough geometry of the surface layer and the basement velocity. Subsequently, the ray-tracing method was employed to calculate the wave aeld in the 2-D varying velocity model (@ervený and Prencik, 1983). We obtained a model that could provide a reasonable explanation for both of the observed travel times within a 0.1-s error and the gross features of the amplitudes (Figs. 2 and 3). Our model indicates a lateral varia- tion of the surface layer. Although its velocities range from 1.7 to $4.3 \mathrm{~km} / \mathrm{s}$, signincant velocity changes are found at distances of 30 and 70-80 km (Fig. 3). The thickness of the surface layer is $0.2-3 \mathrm{~km}$ in the northern part of the prode, while it is nearly $4-5 \mathrm{~km}$ in the southern part. The velocity of the top of the uppermost crystalline crust is $6.0 \mathrm{~km} / \mathrm{s}$, and this $6.0-\mathrm{km} / \mathrm{s}$ layer exists beneath the entire onshore survey line. In Fig. 2, the later phase, L1, is a redector from an interface located at a depth of $9 \mathrm{~km}$ beneath the central part of survey line, whose strong amplitudes required a velocity jump of $0.3 \mathrm{~km} / \mathrm{s}$ at the corresponding interface (Fig. 3). The resultant velocity below the interface is $6.4 \mathrm{~km} / \mathrm{s}$. As described in Section 3.2, the data from the digital telemetry seismic recording system strongly indicate mid-crustal reaectors below a depth of $10-12 \mathrm{~km}$ in the northern part of the pronle.

\subsection{Renection image}

To image the mid and lower crustal structures in the northern part of the pronle, the data sets ( $\mathrm{J} 1$ and $\mathrm{J} 4$ ) recoded by the digital telemetry seismic recording system were processed using the seismic redection technique. The imaging was performed using conventional common midpoint 
$\mathrm{N}$

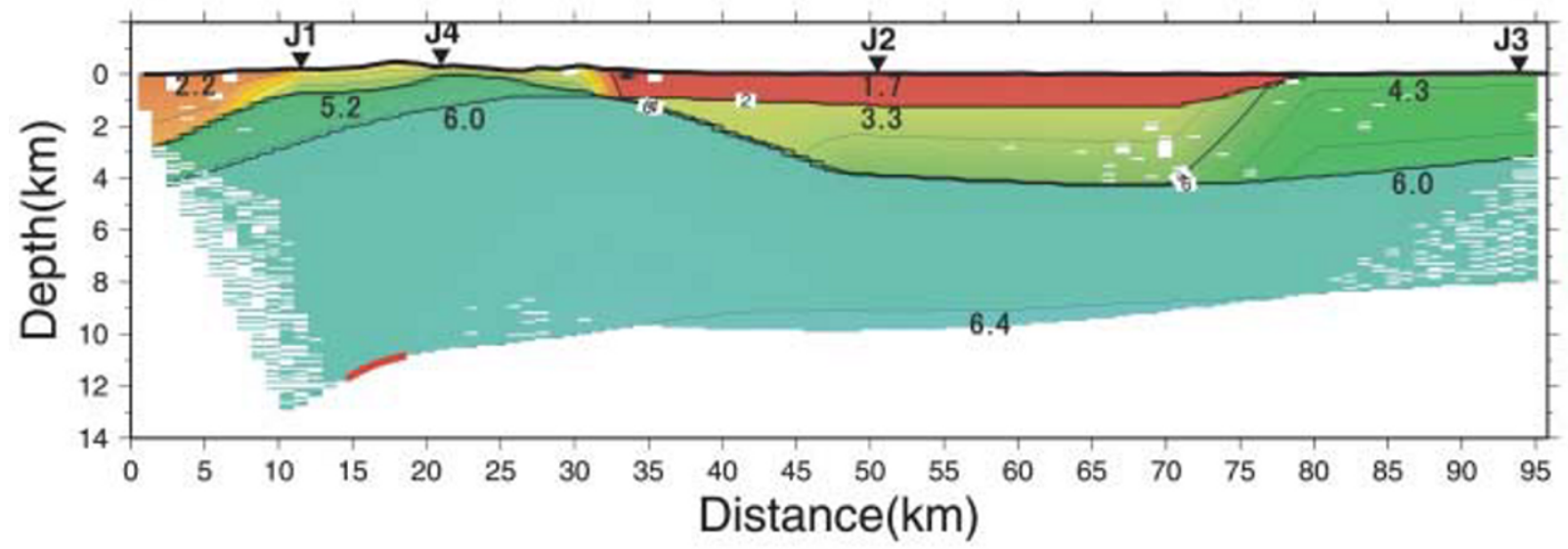

$\begin{array}{lllllllllllll}1.7 & 2.1 & 2.5 & 2.9 & 3.3 & 3.7 & 4.1 & 4.5 & 4.9 & 5.3 & 5.7 & 6.1 & 6.5[\mathrm{~km} / \mathrm{s}]\end{array}$

Fig. 3. $P$-wave velocity structure derived by a 2-D ray-tracing method. The horizontal axis represents the distance from the north end of the onshore survey line. The shot positions are denoted by solid triangles at the top of gure. The $P$-wave velocities are shown using a color scale. The numerals indicate the $\mathrm{P}$-wave velocities in $\mathrm{km} / \mathrm{s}$. The solid counter lines denote the $P$-wave velocity in $\mathrm{km} / \mathrm{s}$. The counter interval is $0.4 \mathrm{~km} / \mathrm{s}$. The areas with no ray coverage are represented as blanks. The red line denotes the mid-crustal redector (R1) obtained from the seismic redection image (Fig. 5).

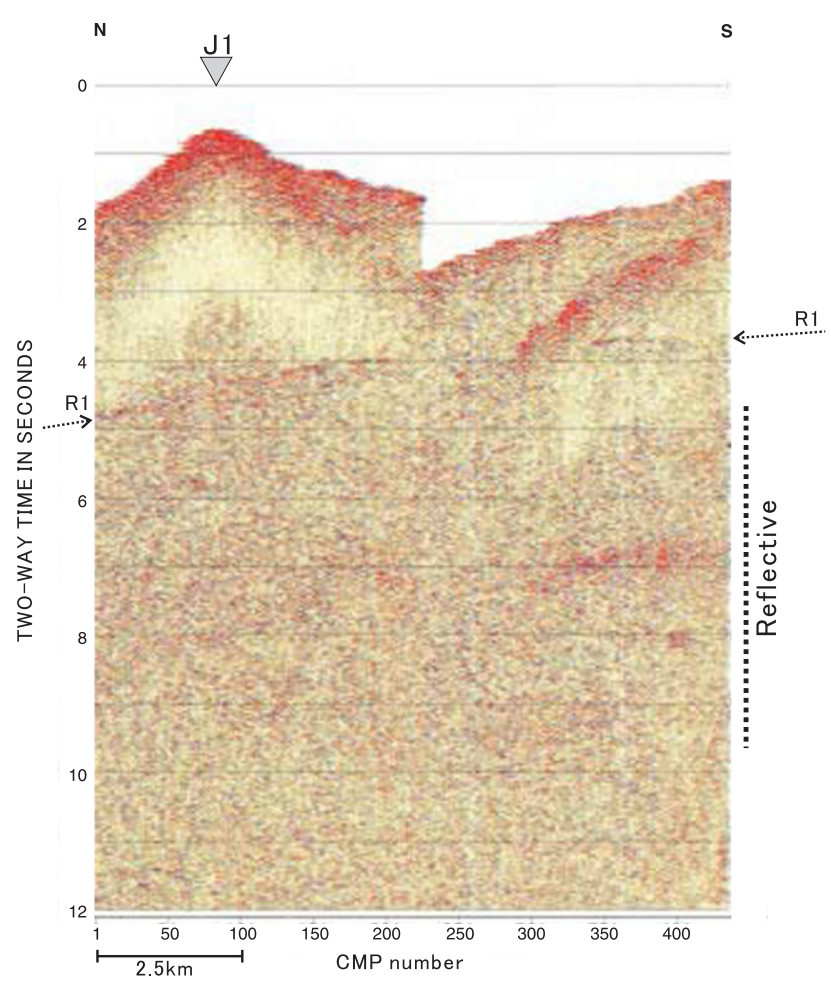

Fig. 4. Unmigrated stacked time section of the deep renection survey using a digital telemetry recording system. See text for detailed explanation.

(CMP) processing steps, including post-stack migration and depth conversion. A static correction for the shallow lowvelocity layer was applied based on the refraction analysis by using the extended time-term method (Iwasaki, 2002). The length of the automatic gain control operator is $4 \mathrm{~s}$. The normal moveout and depth conversion velocities were based on the 2-D velocity structure (Fig. 3). In Figs. 4 and 5,

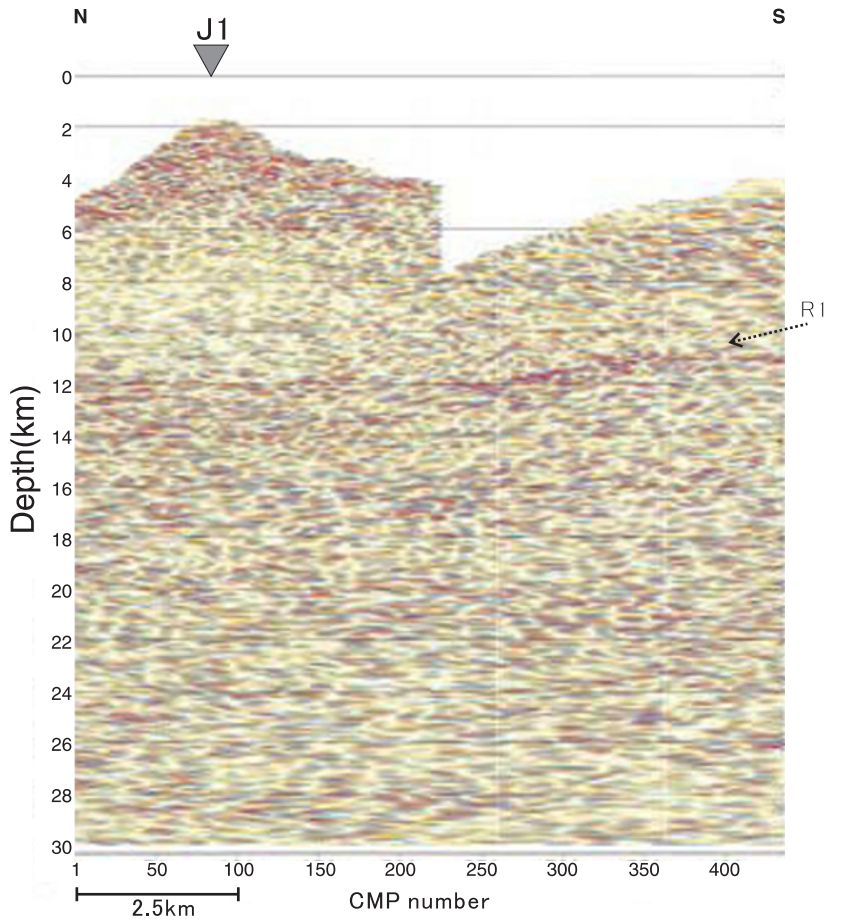

Fig. 5. Post-stack migrated depth section of the deep renection survey using a digital telemetry recording system. See text for detailed explanation.

the CMP stacked images show several features of the deeper part of the crust. In the unmigrated time section (Fig. 4), a clear recector (R1) is found at a 4-4.4 s two-way travel time (TWT), below which a number of renectors are distributed down to a 9-10 s TWT. Figure 5 shows the migrated depth section in which the northward dipping renector (R1) was mapped at a depth of 10-12 km. 


\section{Discussion and Conclusions}

The $P$-wave velocity structure beneath eastern Hokkaido (Fig. 3) correlates well with the surface geology (GSJ, 1992, see Fig. 1). Namely, a surface layer with a velocity of $2.9-4.0 \mathrm{~km} / \mathrm{s}$ in the northern part of our model represents Miocene to Quaternary volcanic rocks. The Nemuro group, which is mainly composed of upper Cretaceous to Paleocene sediments in the southern part of our pronle, has a velocity of $4.3 \mathrm{~km} / \mathrm{s}$. The $1.7-\mathrm{km} / \mathrm{s}$ layer beneath the Konsen Plain corresponds to a Neogene and Quaternary sedimentary layer. The analysis of drill cores at Nishibetsu (NSK1 in Fig. 1) indicates that the boundary between the upper Eocene and Cretaceous units is located at a depth of $900 \mathrm{~m}$ (JNOC, 2002), which is almost consistent with our results. A density model constructed from the Bouguer anomaly data beneath eastern Hokkaido (Morijiri et al., 2000) indicates that the maximum thickness of the Cenozoic deposits is approximately $1.7 \mathrm{~km}$ in the Konsen Plain, showing good correspondence to our $P$-wave velocity model. In the Konsen Plain, several seismic redection experiments were conducted (JNOC, 1985, 1990, 2002). The VK89-A line crosses our survey line (Fig. 1). On this pronle, clear redectors are recognized at a depth of 4-5 km beneath the point of intersection with our survey line. The top of the $6.0-\mathrm{km} / \mathrm{s}$ layer in our model is almost consistent with that of the renector. The lower side of the renector that corresponds to the $6-\mathrm{km} / \mathrm{s}$ layer is interpreted as the Cretaceous Nemuro group (JNOC, 1990).

The deeper structure beneath our pronle is characterized by a $6.4 \mathrm{~km} / \mathrm{s}$ layer in its southern part and mid-crustal redective zone in its northern part. From our seismic data, however, it is not clarined that the top of the $6.4 \mathrm{~km} / \mathrm{s}$ layer in the southern part of the prodle corresponds to the reqector $\mathrm{R} 1$ in the northern part of the prople. It also remains unclear that the $6.4 \mathrm{~km} / \mathrm{s}$ layer contains a redective zone as found in the northern part of the proule.

A magneto-telluric (MT) survey conducted across eastern Hokkaido revealed a highly resistive zone at a depth of 10-20 km below the forearc side (Satoh et al., 2001). The depth of the top of the highly resistive zone is almost consistent with that of the mid-crustal interface beneath the central part of our survey line. It is also noted that this highly resistive zone does not extend to the northern part of the line. A highly positive gravity anomaly is observed in and around the Nemuro Peninsula (Morijiri et al., 2000). These data suggest the existence of structural differences between the northern and southern parts of easternmost Hokkaido. Granodiorite formed by Cretaceous-earliest Paleogene islandarc magmatism (54-79 Ma) was found in the southern part of eastern Hokkaido in the Kushiro-Nemuro area (Ogasawara et al., 1997). Based on studies of K-Ar age data, volcanic stratigraphy, and physical volcanology, Hirose and Nakagawa (1999) concluded that subduction-related islandarc volcanism occurred at least up to $9 \mathrm{Ma}$ in the northern part of eastern Hokkaido. These results suggest that the materials forming the northern part of the southwestern Kuril arc are younger than those of the southern part.

Finally, we compare our results with those from other island arcs. As stated above, the southwestern margin of the Kuril arc has a $6.0-\mathrm{km} / \mathrm{s}$ layer. This characteristic is similar to the case of the Izu-Bonin arc, which also evolved as an oceanic island arc. According to a wide-angle redection survey (Suyehiro et al., 1996; Tahahashi et al., 1998), the Izu-Bonin arc has a mid-crustal layer with a velocity of $6.0-6.3 \mathrm{~km} / \mathrm{s}$. Two major volcanic episodes occurred in this arc before and after the back-arc spreading (Karig and Moore, 1975). Takahashiet al. (1998) indicate that the midcrustal layer of the Izu-Bonin arc is probably a granitic layer formed in more than two volcanic episodes. On the other hand, the central Aleutian arc, which is an oceanic island arc built on old oceanic crust, has no mid-crustal layer with a velocity of $6.0 \mathrm{~km} / \mathrm{s}$ (Holbrook et al., 1999). According to Scholl et al. (1987), the arc magmatism in the Aleutians probably started in the early to middle Eocene (55-50 Ma). The Aleutian Islands are volcanically active, just like the Kuril Islands, and the Tertiary-Quaternary volcanic rocks are exposed (e.g. Beikman, 1980). However, a back-arc spreading zone has never developed in the Aleutians, which distinguishes it from the Izu-Bonin and southwestern Kuril arcs. In the central Aleutian, the redective lower crust, which is often seen in continental crusts, is not recognized (Holbrook et al., 1999). From these observations, Holbrook et al. (1999) proposed that the mid-crustal layer with a velocity of $6.0 \mathrm{~km} / \mathrm{s}$ and seismic renectivity are not native to oceanic island arcs and therefore additional processes are required. Namely, intra-crustal melting for forming a midcrustal layer with a velocity of $6.0 \mathrm{~km} / \mathrm{s}$ and delamination of a manc lower crust must occur to become "continental" in character. These comparisons indicate that the southern margin of the Kuril arc is in a matured state of the oceanic island arc.

Acknowledgments. We are very grateful to the reviewers for their useful comments regarding our manuscript. This experiment was supported by a grant from the Japan Agency for Marine-Earth Science and Technology (JAMSTEC). We are grateful to Y. Ichinose, Y. Inoue, M. Kobayashi, M. Saka, K. Sakai, T. Tagami, Y. Hirata, R. Miura, and M. Onishi for the data acquisition. We gratefully acknowledge K. Ogasawara and S. Omori for their efforts in the data acquisition and processing. We also acknowledge the productive discussions conducted with A. Nakanishi.

\section{References}

Arita, K., T. Ikawa, T. Ito, A. Yamamoto, M. Saito, Y. Nishida, H. Satoh, G. Kimura, T. Watanabe, T. Ikawa, and T. Kutoda, Crustal structure and tectonics of the Hidaka collision zone, Hokkaido (Japan), revealed by vibroseis seismic reaection and gravity surveys, Tectonophysics, 290, 197-210, 1998.

Beikman, H. M., Geological map of Alaska: U.S. Geological Survey Special Map 1:250,000 scale, 1980.

@ervený and Prencuk, Program package SEIS83, Charles University, Prague, 1983.

Geological Survey of Japan, 1:1,000,000 Geological map of Japan, Third edition, 1992.

Hirose, W. and M. Nakagawa, Neogene volcanism in Central-Eastern Hokkaido: Beginning and evolution of arc volcanism inferred from volcanological parameters and geochemistry, J. Geol Soc. Jpn., 105, 247$265,1999$.

Holbrook, W., D. Lizarralde, S. McGeary, N. Bangs, and J. Deibold, Structure and composition of the Aleutian island arc and implications for continental crustal growth, Geology, 27, 31-34, 1999.

Iwasaki, T., K. Adachi, T. Moriya, H. Miyamachi, T. Matsushima, K. Miyashita, T. Takeda, T. Taira, T. Yamada, and K. Ohtake, Upper and middle crustal deformation of arc-arc collision across Hokkaido, Japan, inferred from seismic refraction/wide-angle redection experiments, Tectonophysics, 388, 59-73, 2004. 
Iwasaki, T., Extended time-term method for identifying lateral structural variations from seismic refraction data, Earth Planets Space, 54, 663$677,2002$.

Iwasaki, T., O. Ozel, T. Moriya, S. Sakai, S. Suzuki, G. Aoki, T. Maeda, and T. Iidaka, Lateral structural variation across a collision zone in central Hokkaido, Japan, as revealed by wide-angle seismic experiments, Geophys. J. Int., 132, 435-457, 1998.

Japan National Oil Corporation, Report on basic geophysical exploration in onshore Bekkai area, 45 pp., JNOC, Tokyo, 2002 (in Japanese).

Japan National Oil Corporation, Report on basic geophysical exploration in onshore Konsen area, 22 pp., JNOC, Tokyo, 1990 (in Japanese).

Japan National Oil Corporation, Report on basic geophysical exploration in Konsen area, 39 pp., JNOC, Tokyo, 1985 (in Japanese).

Japan National Oil Corporation, Report on basic geophysical exploration in Abasiri area, 15 pp., JNOC, Tokyo, 1984 (in Japanese).

Karig, D. E. and G. F. Moore, Tectonic complexities in the Bonin arc trench, Tectonophysics, 27, 97-118, 1975.

Kawamura, N., J. Tajika, T. Kawamura, and Y. Kato, Constitution and occurrences of the Paleozoic and Mesozoic formations in SW Hokkaido, northern Japan, Monogr. Assoc. Geol. Collab. Jpn., 31, 17-32, 1986 (in Japanese with English abstract).

Kimura, G., Collision orogeny at arc-arc junctions in the Japanese Island, The Island Arc, 5, 262-275, 1996.

Kimura, G., The latest Cretaceous-early Paleogene rapid growth of accretionary complex and exhumation of high pressure series metamorphic rocks in northwestern Pacific margin, J. Geophys. Res., 99, 2214722164, 1994.

Kimura, G., Oblique subduction and collision: forearc tectonics of the Kuril arc, Geology, 14, 404-407, 1986.

Kimura, G. and K. Tamakai, Tectonic framework of the Kuril arc since its initiation, in Formation of Active Ocean Margins, edited by N. Nasu et al., 641-676 pp., Terrapub, Tokyo, 1985.

Morijiri, R., T. Hiroshima, Y. Murata, M. Makino, and M. Komazawa, Bouguer gravity anomalies in the eastern part of Hokkaido, Japan, Bull. Geol. Surv. Japan, 51, 537-558, 2000 (in Japanese with English abstract).

Nakanishi, A., A. Smith, S. Miura, T. Tsuru, S. Kodaira, and Koichiro
Obana, Structural factors controlling the coseismic rupture zone of the 1973 Nemuro-Oki earthquake, the southern Kuril Trench seismogenic zone, J. Geophys. Res., 109, doi:10.1029/2003JB002574, 2004.

Ogasawara, M., K. Shibata, and S. Uchiumi, K-Ar ages and petrological characteristics of the granitoid pebbles from the Eocene Beppo Formation in the Kushiro region, Hokkaido, Japan, J. Geol. Soc. Jpn., 104, 516-524, 1998.

Satoh, H., Y. Nishida, Y. Ogawa, M. Takada, and M Uyeshima, Crust and upper mantle resistivity structure in the southwestern end of the Kuril arc as revealed by the joint analysis of conventional MT and network MT data, Earth Planets Space, 53, 829-842, 2001.

Scholl, D. W., T. L. Vallier, and A. J. Stevenson, Geologic evolution and petroleum geology of the Aleutian Ridge, in Geology and Resource Potential of the Continental Margin of Western North America and Adjacent Ocean Basins-Beaufort Sea to Baja California, Earth Science Series, vol. 6, edited by D. W. Scholl, A. Grantz, and J. G. Vedder, 123-155 pp., Circum-Pacific Council for Energy and Mineral Resources, Houston, TX, 1987.

Shinohara, M., N. Hirata, and S. Matsuda, Long-term low-power DAT seismic digital data recorder with GPS clock, Zisin, 50, 119-124, 1997 (in Japanese with English abstract).

Suyehiro, K., N. Takahashi, Y. Ariie, Y. Yokoi, R. Hino, M. Shinohara, T. Kanazawa, N. Hirata, H. Tokuyama, and A. Taira, Continental crust, crustal underplating, and low-Q upper mantle beneath an oceanic island arc, Science, 272, 390-392, 1996.

Takahashi, N., K. Suyehiro, and M. Shinohara, Implications from the seismic crustal structure of the northern Izu-bonin arc, The Island Arc, 7, 383-394, 1998.

Tsumura, N., H. Ikawa, T. Ikawa, M. Shinohara, T. Ito, K. Arita, T. Moriya, G. Kimura, and T. Ikawa, Delamination-wedge structure beneath the Hidaka Collision Zone, Central Hokkaido, Japan, inferred from seismic reflection profiling, Geophys. Res. Lett., 26, 1057-1060, 1999.

E. Kurashimo (e-mail: ekura@eri.u-tokyo.ac.jp), T. Iwasaki, N. Hirata, T. Ito, and Y. Kaneda 